\title{
European ban on stem-cell patents has a silver lining
}

\section{Researchers can work without fear of action over patent infringement.}

\section{BY EWEN CALLAWAY}

$\mathrm{T}$ o hear European stem-cell researchers talk last week, you might have thought that their world was ending. After the European Court of Justice ruled on 18 October that procedures involving human embryonic stem (ES) cells cannot be patented, many responded with shock and dismay.

"This is the worst possible outcome and it's a disaster for Europe," Oliver Brüstle at the University of Bonn, Germany, told Nature shortly after learning that the court had felled his 1999 patent for a method of transforming human ES cells into neurons. Others said that without patent protection, few investors would pay to develop stem-cell therapies for conditions from neurodegenerative diseases to diabetes.

But in the days following the ruling, lawyers, funders and researchers have taken a more moderate view. There are other ways for companies and scientists who commercialize ES cells to protect their inventions in Europe, they say. And some believe that a lack of patents could speed up, rather than suffocate, innovation. "If anything the ruling is an opportunity," says physician scientist Chris Mason of University College London. "It's not the end of stem cells in Europe."

The decision by the European Court of Justice, which applies throughout the European Union and cannot be appealed, stems from a 2004 lawsuit brought by Greenpeace. The Amsterdam-based environmental group challenged Brüstle's patent on the grounds that it offended public sentiment and violated European law banning the industrial use of human embryos. A German court agreed, and by 2009 Brüstle's appeal had reached Europe's highest court (see Nature 462, 265; 2009). The language in these legal rulings - that commercial use of human embryos "would be contrary to ethics and public policy", for example alarmed scientists, who spoke out against the court (A. Smith et al. Nature 472, 418; 2011).

The 13 judges of the court's Grand Chamber have now concluded that procedures involving human ES cells cannot be patented if they derive from the destruction of embryos. The ban applies retrospectively, and contrasts sharply with the position in the United States, where scientists face few restrictions on patents relating to ES-cell applications.

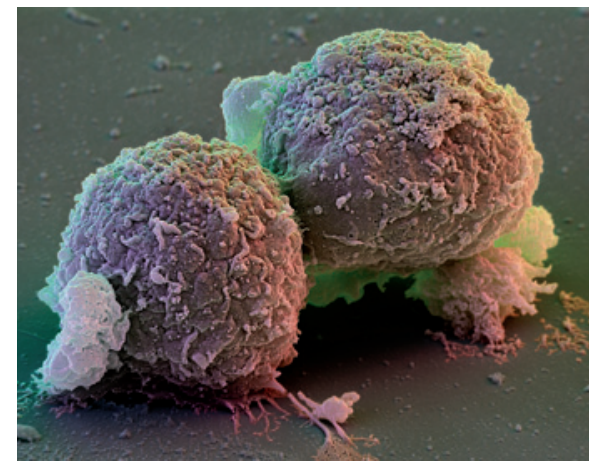

Embryonic stem cells: contrary to ethics and public policy?

“Time will tell how serious it's going to be," says Nick Bassil, an intellectual-property lawyer at Kilburn \& Strode in London, who represents companies developing stem-cell therapies. He adds that it may take years for the European Patent Office, national patent offices and courts to interpret the ruling.

However, even a restrictive interpretation should allow companies to patent the technologies needed to turn human ES cells into treatments, rather than patenting procedures involving the cells themselves. "If the sum total of this market were some cell lines, I would be deeply, deeply worried," says Julian Hitchcock, a life-sciences lawyer at Field Fisher Waterhouse in London. Growth media, equipment and chemicals that help scientists to work with stem cells could all be patented in Europe without running afoul of the high court's ruling, he says. For instance, Peter Coffey at the Institute of Ophthalmology in London and his team are working with the drug giant Pfizer to develop a human-ES-cell-based treatment for macular degeneration, a progressive disease of the retina that causes blindness. Their patents cover the placement of their retinal cells in the eye, not the cells themselves.

Rob Buckle, a programme manager at Britain's Medical Research Council (MRC) in London, agrees that investors will find other ways to protect their intellectual property, and adds

\section{$\rightarrow$ NATURE.COM} Insight on regenerative medicine: go.nature.com/ax5uif also help to ward off copycats who might otherwise exploit the lack of patent protection to rush their own versions of a treatment to market. By keeping many of their manufacturing processes secret until they seek regulatory approval, companies can ensure that knock-offs are unlikely, says Mason. "If I give you my cell line, your chance of knowing what to do with it and copying what I do is zero," he says.

Many of the 20-year patents issued for EScell treatments will probably have expired by the time the treatments reach the clinic anyway, Mason adds. Indeed, the European Medicines Agency offers additional protection for inventions. The drug regulator keeps private for eight years any data that companies submit with their application for marketing approval, and blocks others from using this information for another two.

The ruling may even turn out to be a boon for European stem-cell science, says Mason, creating an anything-goes atmosphere that could attract scientists from abroad. Non-commercial research is generally exempted from patent infringement claims, but many patents cover the cells' use as research tools, creating uncertainty about which methods researchers are allowed to use, says Hitchcock.

A January statement from the Hinxton Group, an influential consortium of scientists and ethicists, had expressed concern that stemcell biology was becoming so thick with broad patents that key areas of the field were being walled off from scientists and entrepreneurs. "With patents gone, it's much easier to do anything," says Mason. .

Additional reporting by Alison Abbott.

\section{CORRECTION}

The News story 'Angry words over East Asian seas' (Nature 478, 293-294; 2011) wrongly implied that Climatic Change took a defined stance on the position of China's border in the South China Sea. In fact, co-editor Michael Oppenheimer merely told the authors of a paper containing a contested map that the journal would make space for any amendments to the map that they may deem appropriate. 